\title{
薬剂師の薬歴に関する意識調査の共分散構造分析による解析
}

\author{
佐 藤 大 峰, ${ }^{*, a}$ 島 森 美 光 ${ }^{b}$
}

\section{Covariance Structure Analysis of Pharmacists' Attitudes toward Medication History}

\author{
Hirotaka SATO ${ }^{*, a}$ and Yoshimitu SHIMAMORI ${ }^{b}$ \\ ${ }^{a}$ Lively Co. Ltd., 2-32-21 Ueno-machi, Kitakami, Iwate 024-0021, Japan, and ${ }^{b}$ Hokkaido Pharmaceutical \\ University School of Pharmacy, 7-1 Katsuraoka-cho, Otaru, Hokkaido 047-0264, Japan
}

(Received December 14, 2010; Accepted February 25, 2011; Published online March 3, 2011)

\begin{abstract}
Keeping track of patients' medication histories is an important component of pharmacy practice. In this study, we conducted a questionnaire survey on medication histories among pharmacists and performed covariance structure analysis to investigate pharmacists' attitudes toward medication histories. The survey was conducted among pharmacists who work at pharmacies. With regard to the questions on medication histories, factor analysis and covariance structure analysis were performed to create a path diagram. The response rate to the questionnaire was $97.0 \%$. The factor analysis revealed six factors, including: "patient assessment", "learning attitude", "practicing the recording of medication histories", "conscious effort to improve medication histories", "uniformity in medication histories" and "issues regarding medication histories". Meanwhile, covariance structure analysis revealed that the five-factor model excluding "issues regarding medication histories" was the best-fitted model. According to this model, it was clear that the pharmacists were extremely conscious about introducing improvements to the content of medication histories. In this study, covariance structure analysis enabled the effective analysis of the attitudes of pharmacists toward medication histories. We believe that creating and conducting a training program to clarify and resolve issues related to medication histories and then reviewing the outcome of such a training program will lead to quality improvement and standardization of the future management of medication histories.
\end{abstract}

Key words — pharmacist; medication history; covariance structure analysis

\section{緒言}

近年，薬剤師業務は薬を中心とする考えから患者 を起点とする考えに変化している. ${ }^{1-3)}$ その根幹を なすものはファーマシューティカルケアの考え方で ある. ファーマシューティカルケアとは, Hepler らによって「患者の Quality of Life（以下，QOL) を改善する明確な結果をもたらすため直接的にまた 責任を持って薬物治療に関連したケアを提供するこ と」と定義されている. ${ }^{4)}$ さらにファーマシューテ イカルケアは，医薬品に関係した諸問題を定式化す ること，そしてそれを解決すること，さらに医薬品 に関係した諸問題を未然に防止することの 3 つの機 能を持ち，薬剤師業務の目標とされている，その中 でも，薬剂服用歴管理指導記録（以下，薬歴）に基 づく業務は薬剤師業務の重要な役割を担ってい

$a$ 株式会社ライブリー, ${ }^{b}$ 北海道薬科大学数学分野

*e-mail: h-satou.lively@wish.ocn.ne.jp
る. ${ }^{1-3,5,6)}$ 諸外国においても，薬剤師の介入とその 意義，その行動と患者のアウトカムに及ぼす影響を 文書で記録することは，ファーマシューティカルケ アを推し進める上で中核をなす重要なこととされて (る. 7)

Problem Oriented System（以下，POS）は，「患 者の持っている医療上の問題に焦点を合わせ，問題 解決のために患者とともに医療スタッフが努力する 一定の作業システムである」と提唱されている. POS の考え方は, 保険薬局の薬歴管理業務にも導 入されてきている. ${ }^{1)}$

保険薬局（以下，薬局）の薬歴管理業務は，処方 鑑査，患者からの聞き取りによる個別状況の把握と 薬学的問題点の抽出・解決そして服薬指導から成り 立つている. 1,2) しかし, 薬歴管理の内容に関しては 個々の薬剂師に依存しているため患者のアウトカム に対してのバラツキがみられる。 そのような個々の 薬剤師によるバラツキをなくすためには，薬歴管理 
の内容に関する標準化が必要となる。しかしなが ら, 薬歴管理業務の十分な標準化がなされていると は言えない。

現在，様々な薬歴に関する著書が出版されてい る. ${ }^{1-3,5,6)}$ また，諸外国においても，薬歴に関する 多くの評価研究がなされており,7) わが国において も病院における薬剤師の薬歴に関する研究がなされ ている. ${ }^{8)}$ しかし，薬局における薬剤師が薬歴に対 してどのような意識を持って業務しているかについ ての研究報告はされていない。薬局薬剤師の薬歴に 関する意識を明確化することは，薬歴管理の標準化 に役立つものと考える．意識を明確化する上で，薬 凨師の薬歴に対する日々感じている考えと潜在する 考えとの因果関係を解明する必要がある．近年，観 測可能な変数と潜在する変数との因果関係を解明す る統計方法に共分散構造分析がある. ${ }^{9-12)}$ さらに薬 剤師における意識を解明する研究においては，共分 散構造分析による解析が有効であることが報告され ている. ${ }^{13-16)}$ 本研究では，株式会社ライブリーの薬 局に勤務する薬剤師が薬歴に対してどのように考え ているかについてアンケート調査を行い，その結果 を基に，薬局薬剤師の薬歴に関する意識を明確にす ることを目的として共分散構造分析による解析を行 つた. ${ }^{9-12)}$

\section{方法}

1. 薬剤師に対するアンケート アンケート は，株式会社ライブリーの薬局（以下，当薬局）に 勤務する薬剤師を対象に実施した。調査方法は，ア ンケート内容を各薬局へメールにて送付した。その 際，アンケート提出の有無又は回答内容によって回 答者への不利益にならないことを説明した内容も送 付した。ささにアンケート提出の有無や回答内容等 個人の特定を会社又は上司に確認されるのを避ける ため，回答者が記入後封印した，回収方法は，個人 又は各薬局で取りまとめて大学へ直接郵送する形式 で回収した。調查期間は 2009 年 9 月上旬から 2009 年 9 月中旬までとした。

質問項目は，性別，薬剂師実務経験年数，当薬局 勤務年数の 3 項目と薬歴に関する 42 項目の構成と した (Table 1)。薬歴に関する項目に関しては，5 段階評定とした。「強くそう思う」を 5 とし，「全く そう思わない」を 1 とした。質問項目については略
称（観測変数）を用いる（Table 2）。

回収されたアンケートの処理は, Microsoft Excel （以下，Excel）又は SPSS 社 SPSS12.0J（以下, SPSS) で行った.

2. アンケートデータの解析 薬歴に関する項 目に関して，最尤法，プロマックス回転で因子分析 を行った。因子分析の結果を基に，共分散構造分析 を行い，パス図を作成した。因子分析は，SPSS を 用いた。共分散構造分析，パス図の作成はSPSS 社 AMOS version 5.0 日本語版（以下，AMOS）を用 いた.

\section{結果}

1. アンケート回答者の概要アンケートの回 答は，107 人の薬剂師（回収率 $100.0 \%$ ）から得ら れた。そのうち，全項目に回答があった有効回答は 104 人（有効回答率 $97.0 \%$ ）であった。回答した薬 剂師は，男性が $36.5 \%$ ，女性が $63.5 \%$ という結果 であった。薬剤師実務経験年数は，10 年を境に約 $50 \%$ すとつう結果であった．当薬局勤務年数は, 10 年未満が $90 \%$ 以上を占める結果となった（Table $3)$.

2. 薬歴に対する意識に関する仮説モデル＼cjkstart薬 剤師の薬歴に対する意識に関して，それぞれの相互 関係の仮説を以下のように立案した.

日々の薬歴管理業務から，薬剤師は薬歴に知識を 実践につなげる技能が不足している.1) そこで薬歴 の理解や実践，問題点を明確化するため「薬歴の意 義」「薬歴の実践」「薬歴の問題点」の 3 因子を設定 した。この 3 因子を上位概念と設定した。これらの 上位概念が影響を与えるものとして薬歴スキルを向 上するための理解や実践を考え「薬歴向上への意識」 「薬歴向上への取り組み」の 2 因子を設定した。こ の 2 因子を下位概念と設定した。この上位概念が下 位概念へ影響を与えるモデルとした仮説モデルを示 す (Fig. 1).

モデルの内容は以下の通りである，それぞれの上 位概念は，互いに影響し合うと仮定した。下位概念 への影響については，上位概念の 3 因子それぞれが 強く影響していると仮定した。 また，向上意識が高 まると取り組みへの意識が高まると仮定し，これを 仮説モデルと設定した。

3. 因子分析 薬歴に関するアンケート 42 項 
Table 1. Questionnaire

\begin{tabular}{|c|c|}
\hline $\begin{array}{l}\text { 1. 薬剂師のあなたについてお伺いします. } \\
\text { 該当するのに○をつけてください. }\end{array}$ & 答 \\
\hline Q1. 性別 & 2 女 \\
\hline Q2. 経験年数（当社以外も含めて薬局等医療現場の通算勤務年数） & 年 \\
\hline Q3. 勤務年数（当社での勤務年数） & 年 \\
\hline $\begin{array}{l}\text { 2. 薬歴管理業務などについてお伺いします. } \\
\text { 以下の質問内容について, 最も近いものの数字に○をつけてくだ } \\
\text { さい. }\end{array}$ & $\begin{array}{c}5 \cdot \cdots \cdot 4 \cdot \cdots \cdot 3 \cdot \cdots \cdot 2 \cdot \cdots \cdot 1 \\
\text { そ強く } \\
\text { そ思う }\end{array}$ \\
\hline $\begin{array}{l}\text { Q1. 医薬品を十分考慮しっ患者・病態にあった医薬品の適正な選 } \\
\text { 択・使用を行ってると思う. }\end{array}$ & $5 \cdot \cdot \cdot 4 \cdot \cdot \cdot 3 \cdot \cdot \cdot 2 \cdot \cdot \cdot 1$ \\
\hline Q2.＼cjkstart薬歴は SOAP 記録で行うのが良い. & $5 \cdot \cdots 4 \cdot \cdot \cdot 3 \cdot \cdot \cdot 2 \cdot \cdot \cdot 1$ \\
\hline Q3. 現時点での自分の薬歴管理に満足している. & $5 \cdot \cdots 4 \cdot \cdot \cdot 3 \cdot \cdot \cdot 2 \cdot \cdots 1$ \\
\hline Q4. 薬歴管理において (薬局内又は自分), 薬剤師の判断がある. & $5 \cdot \cdots 4 \cdot \cdot \cdot 3 \cdot \cdot \cdot 2 \cdot \cdots 1$ \\
\hline Q5. SOAP 記録には時間がかかる. & $5 \cdot \cdot \cdot 4 \cdot \cdot \cdot 3 \cdot \cdot \cdot 2 \cdot \cdot \cdot 1$ \\
\hline Q6. 患者ケアの結果を評価した薬歴管理を実施している. & $5 \cdot \cdot \cdot 4 \cdot \cdot \cdot 3 \cdot \cdot \cdot 2 \cdot \cdot \cdot 1$ \\
\hline Q7. 薬学的評価をするのは難しい. & $5 \cdot \cdot \cdot 4 \cdot \cdot \cdot 3 \cdot \cdot \cdot 2 \cdot \cdot \cdot 1$ \\
\hline $\begin{array}{l}\text { Q8. 薬歴管理において (薬局内又は自分), 患者情報の確認や指導 } \\
\text { 内討を行つてる. }\end{array}$ & $5 \cdot \cdot \cdot 4 \cdot \cdot \cdot 3 \cdot \cdot \cdot 2 \cdot \cdot \cdot 1$ \\
\hline Q9. 薬歴に必要な臨床判断と意思決定能力を学ぶ姿勢がある. & $5 \cdot \cdot \cdot 4 \cdot \cdot \cdot 3 \cdot \cdot \cdot 2 \cdot \cdot \cdot 1$ \\
\hline Q10. 薬学的問題点をあげるのは難しい. & $5 \cdot \cdot \cdot 4 \cdot \cdot \cdot 3 \cdot \cdot \cdot 2 \cdot \cdot \cdot 1$ \\
\hline Q11. 患者の個別状況を評価する姿勢で行っている. & $5 \cdot \cdot \cdot 4 \cdot \cdot \cdot \cdot 3 \cdot \cdot \cdot 2 \cdot \cdot \cdot \cdot 1$ \\
\hline Q12. 抽出した薬学的問題点を薬歴の表書きに整理している. & $5 \cdot \cdot \cdot 4 \cdot \cdot \cdot 3 \cdot \cdot \cdot 2 \cdot \cdot \cdot 1$ \\
\hline $\begin{array}{l}\text { Q13. 薬局内又は全体で, 薬歴に関するワークショップを取り組む姿 } \\
\text { 勢があ. }\end{array}$ & $5 \cdot \cdot \cdot 4 \cdot \cdot \cdot 3 \cdot \cdot \cdot 2 \cdot \cdot \cdot 1$ \\
\hline $\begin{array}{l}\text { Q14. 薬歴に必要な包括的・継続的なケアの視点とプランニングを学 } \\
\text { ぶ勢かる. }\end{array}$ & $5 \cdot \cdot \cdot 4 \cdot \cdot \cdot 3 \cdot \cdot \cdot 2 \cdot \cdot \cdot 1$ \\
\hline Q15. 薬歴管理において（薬局内又は自分），前の記録を参照・活用 & $5 \cdot \cdot \cdot 4 \cdot \cdot \cdot 3 \cdot \cdot \cdot 2 \cdot \cdot \cdot 1$ \\
\hline Q16. 自分の薬歴管理を他の人に評価してもらいたい. & $5 \cdot \cdot \cdot 4 \cdot \cdot \cdot 3 \cdot \cdot \cdot 2 \cdot \cdot \cdot 1$ \\
\hline $\begin{array}{l}\text { Q17. 薬局内又は全体で, 薬歴に関する症例検討を取り組む姿勢があ } \\
\text { る. }\end{array}$ & $5 \cdot \cdots 4 \cdot \cdot 3 \cdot \cdot \cdot 2 \cdot \cdot 1$ \\
\hline Q18．会社全体での薬歴に統一性がある. & $5 \cdot \cdot \cdot 4 \cdot \cdot \cdot 3 \cdot \cdot \cdot 2 \cdot \cdot \cdot 1$ \\
\hline Q19. 患者アウトカムを思考した薬歴管理を行う姿勢がある. & $5 \cdot \cdot \cdot 4 \cdot \cdot \cdot 3 \cdot \cdot \cdot 2 \cdot \cdot \cdot \cdot 1$ \\
\hline $\begin{array}{l}\text { Q20. 薬歴管理において, 患者の医療上の問題に焦点を合わせ, 問題 } \\
\text { 決をてる. }\end{array}$ & $5 \cdot \cdot \cdot 4 \cdot \cdot \cdot 3 \cdot \cdot \cdot \cdot 2 \cdot \cdot \cdot 1$ \\
\hline Q21．薬局内での薬歴に統一性がある. & $5 \cdot \cdots 4 \cdot \cdot \cdot 3 \cdot \cdot \cdot 2 \cdot \cdot \cdot 1$ \\
\hline Q22. 薬歴管理において（薬局内又は自分）, 一覧性がある. & $5 \cdot \cdot \cdot 4 \cdot \cdot \cdot 3 \cdot \cdot \cdot \cdot 2 \cdot \cdot \cdot 1$ \\
\hline Q23. 適切な薬歴管理は，患者ケアに有効と思う. & $5 \cdot \cdot \cdot 4 \cdot \cdot \cdot 3 \cdot \cdot \cdot \cdot 2 \cdot \cdot \cdot 1$ \\
\hline Q24. 薬歴に必要な情報評価と論理的な思考能力を学ぶ姿勢がある. & $5 \cdot \cdot \cdot 4 \cdot \cdot \cdot \cdot 3 \cdot \cdot \cdot 2 \cdot \cdot \cdot \cdot 1$ \\
\hline Q25. 患者の個別状況の評価から薬学的問題点の抽出を行っている. & $5 \cdot \cdot \cdot 4 \cdot \cdot \cdot 3 \cdot \cdot \cdot \cdot 2 \cdot \cdot \cdot 1$ \\
\hline $\begin{array}{l}\text { Q26. 薬歴に関する勉強会の後, 自分の薬歴管理の内容を変える姿勢 } \\
\text { がある. }\end{array}$ & $5 \cdot \cdot \cdot 4 \cdot \cdot \cdot 3 \cdot \cdot \cdot 2 \cdot \cdot \cdot \cdot 1$ \\
\hline Q27． 次回実施項目を引き継いだ薬歴管理を実施している. & $5 \cdot \cdot \cdot 4 \cdot \cdot \cdot 3 \cdot \cdot \cdot 2 \cdot \cdot \cdot \cdot 1$ \\
\hline Q28. 薬歴において, 患者の個別状況の把握に重点をおいている. & $5 \cdot \cdot \cdot 4 \cdot \cdot \cdot 3 \cdot \cdot \cdot 2 \cdot \cdot \cdot \cdot 1$ \\
\hline Q29． 解決方法の立案を立てるのは難しい. & $5 \cdot \cdot \cdot 4 \cdot \cdot \cdot \cdot 3 \cdot \cdot \cdot 2 \cdot \cdot \cdot \cdot 1$ \\
\hline
\end{tabular}


Table 1. (Continued)

\begin{tabular}{|c|c|}
\hline Q30. 患者ケア計画を具体的に文書にしている. & $5 \cdot \cdots 4 \cdot \cdots \cdot 3 \cdot \cdot 2 \cdot \cdots \cdot 1$ \\
\hline Q31．薬歴管理において（薬局内又は自分），継続性がある. & $5 \cdot \cdot \cdot 4 \cdot \cdot \cdot \cdot 3 \cdot \cdot \cdot 2 \cdot \cdot \cdot 1$ \\
\hline Q32. 薬局内で薬歴に関する検討会を行っている姿勢がある. & $5 \cdot \cdot \cdot 4 \cdot \cdot \cdot 3 \cdot \cdot \cdot \cdot 2 \cdot \cdot \cdot 1$ \\
\hline Q33. 薬歴において, 医師の診断名・検査值がないと書けない. & $5 \cdot \cdot \cdot 4 \cdot \cdot \cdot 3 \cdot \cdot \cdot 2 \cdot \cdot \cdot 1$ \\
\hline $\begin{array}{l}\text { Q34. 薬歴管理において（薬局内又は自分）, 不足している点・不適 } \\
\text { 切な点があ. }\end{array}$ & $5 \cdot \cdot \cdot 4 \cdot \cdot \cdot 3 \cdot \cdot \cdot 2 \cdot \cdot \cdot 1$ \\
\hline $\begin{array}{l}\text { Q35. 医薬品に関する問題を特定・解決・防止した薬歴管理 } \\
\text { いる. }\end{array}$ & $5 \cdot \cdot \cdot 4 \cdot \cdot \cdot 3 \cdot \cdot \cdot 2 \cdot \cdot \cdot \cdot 1$ \\
\hline Q36. 抽出した薬学的問題点を実行できない. & $5 \cdot \cdot \cdot 4 \cdot \cdot \cdot 3 \cdot \cdot \cdot 2 \cdot \cdot \cdot 1$ \\
\hline Q37. 薬歴に関する勉強会の後, 薬局内で取り組む姿勢がある. & $5 \cdot \cdot \cdot 4 \cdot \cdot \cdot 3 \cdot \cdot \cdot \cdot 2 \cdot \cdot \cdot 1$ \\
\hline Q38. 薬歴管理の妥当性を評価し, 今後のケアに役立てる姿勢がある. & $5 \cdot \cdot \cdot 4 \cdot \cdot \cdot 3 \cdot \cdot \cdot 2 \cdot \cdot \cdot 1$ \\
\hline $\begin{array}{l}\text { Q39. 抽出した問題点を包括的・継続的な患者ケア計画の立案を行つ } \\
\text { ている. }\end{array}$ & $5 \cdot \cdots 4 \cdot \cdots 3 \cdot \cdot 2 \cdot \cdots 1$ \\
\hline Q40. 立案した患者ケア計画に対して薬歴管理を実施している. & $5 \cdot \cdot \cdot 4 \cdot \cdot \cdot 3 \cdot \cdot \cdot 2 \cdot \cdot \cdot \cdot 1$ \\
\hline Q41. 外部講師による症例検討会は, 薬歴管理に有効と思う. & $5 \cdot \cdot \cdot 4 \cdot \cdot \cdot 3 \cdot \cdot \cdot 2 \cdot \cdot \cdot 1$ \\
\hline Q42. 薬歴管理において, 疫学等のデータを活用し記載している. & $5 \cdot \cdots 4 \cdot \cdots \cdot 3 \cdot \cdot 2 \cdot \cdots \cdot 1$ \\
\hline
\end{tabular}

*は逆転項目を意味する.

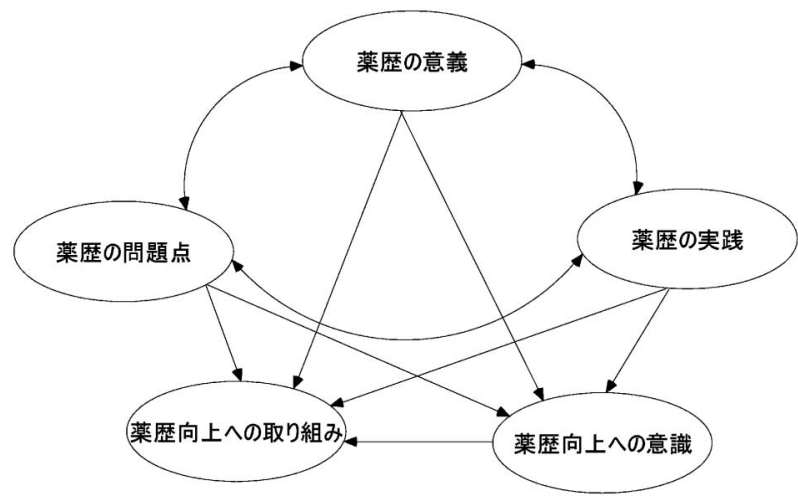

Fig. 1. Hypothetical Model

目すべてを対象として因子分析を行った．その結果 から因子負荷量 0.45 未満のものを除外したところ, 6 つの因子が抽出された (Table 4). 第 1 の因子に は，患者情報やケアなど患者の情報を評価，実践す る項目が含まれることから「患者アセスメント」と 解釈した．第 2 の因子には，外部講師による検討会 や変化したい意識など学習に関する項目が含まれる ことから「学ぶ姿勢」と解釈した。第 3 の因子には, POS や患者個別状況把握など業務に関する項目が 含まれることから「薬歴の実践」と解䣋した。第 4 の因子には, ワークショップや検討会などスキル向 上に関する項目が含まれることから「薬歴向上意識」
と解釈した，第 5 の因子には，会社や薬局の統一性 など薬歴統一に関する項目が含まれることから「薬 歴の統一性」と解釈した，第 6 の因子には，プロブ レムの抽出難や実行難など薬歴の困難に関する項目 が含まれることから「薬歴の問題点」と解釈した (Table 5).

4. 共分散構造分析 因子分析の結果と仮説モ デルを基に，共分散構造分析を行った。まず，因子 分析で抽出された $6 \supset$ つ因子を潜在変数として分析 を行った（Fig. 2)。因子から観測変数へのパス係 数は，ワルド検定の結果すべて $5 \%$ 水準で有意であ った。適合度指標である GFI は 0.795, AGFI は 0.746, RMSEA が 0.069 とある程度あてはまりのよ いモデルであった，潜在変数間において，「薬歴の 問題点」は他の潜在変数から影響を受けるがパス係 数は低いか負の係数であった．ワルド検定の結果 も，すべて 5\%水準で有意でなかった.

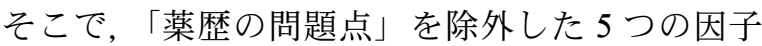
での分析を行った（Fig. 3)。このモデルでも，因 子から観測変数へのパス係数のワルド検定結果は 5 \%水準で有意であった。適合度指標も GFI は 0.813, AGFI は 0.761, RMSEA が 0.072 と先ほどの モデルよりもあてはまりのよいモデルとなった．両 モデルおいて，「患者アセスメント」と「薬歴の実 
Table 2. Abbreviated Expressions of the Questions

\begin{tabular}{|c|c|}
\hline 質問番号 & 略称（観測変数） \\
\hline Q1 & ファーマシューティカルケア \\
\hline Q2 & SOAP 記録 \\
\hline Q3 & 薬歴への満足 \\
\hline Q4 & 薬剂師判断 \\
\hline Q5 & SOAP 記載難 \\
\hline Q6 & 患者ケア評価 \\
\hline Q7 & 評価の実行難 \\
\hline Q8 & 患者情報の確認・指導検討 \\
\hline Q9 & 臨床判断・意思決定能力 \\
\hline Q10 & プロブレムリスト抽出難 \\
\hline Q11 & 患者個別状況把握 \\
\hline Q12 & プロブレムリスト整理 \\
\hline Q13 & ワークショップ開催 \\
\hline Q14 & ケアの視点・プランニング \\
\hline Q15* & 薬歴参照・活用 \\
\hline Q16 & 薬歴評価希望 \\
\hline Q17 & 症例検討会開催 \\
\hline Q18 & 会社の薬歴統一性 \\
\hline Q19 & アウトカム思考 \\
\hline Q20 & POS \\
\hline Q21 & 薬局の薬歴統一性 \\
\hline Q22 & 薬歴の一覧性 \\
\hline Q23 & 薬歴管理の有効性 \\
\hline Q24 & 情報評価・思考能力 \\
\hline Q25 & プロブレムリスト抽出 \\
\hline Q26 & 自己変化意識 \\
\hline Q27 & ケアプラン継続 \\
\hline Q28 & 患者個別状況把握 \\
\hline Q29 & ケアプラン立案難 \\
\hline Q30 & ケアプラン文書化 \\
\hline Q31 & 薬歴の継続性 \\
\hline Q32 & 薬局内検討会開催 \\
\hline Q33 & 客観的情報の不足 \\
\hline Q34* & 薬歴の内容不足・不適切 \\
\hline Q35 & ファーマシューティカルケアの特性 \\
\hline Q36 & プロブレムの実行難 \\
\hline Q37 & 薬局内統一意識 \\
\hline Q38 & オーディットの実施 \\
\hline Q39 & ケアプラン作成 \\
\hline Q40 & ケアプラン実施 \\
\hline Q41 & 外部講師症例検討会 \\
\hline Q42 & EBM の活用 \\
\hline
\end{tabular}

* は逆転項目を意味する.
Table 3. The Attributs of Pharmacists

\begin{tabular}{|c|c|c|c|}
\hline \multirow{2}{*}{ 属 } & \multirow{2}{*}{ 性 } & \multicolumn{2}{|c|}{ 薬 剂 師 } \\
\hline & & $n$ & 比 率 \\
\hline \multirow[t]{2}{*}{ 性 別 } & 男＼cjkstart性 & 38 & $36.5 \%$ \\
\hline & 女＼cjkstart性 & 66 & $63.5 \%$ \\
\hline \multirow[t]{8}{*}{ 経験年数 } & 0-1 年 & 8 & $7.7 \%$ \\
\hline & 1-5 年 & 23 & $22.1 \%$ \\
\hline & 5-10 年 & 23 & $22.1 \%$ \\
\hline & 10-15 年 & 15 & $14.4 \%$ \\
\hline & $15-20$ 年 & 10 & $9.6 \%$ \\
\hline & 20-25 年 & 12 & $11.5 \%$ \\
\hline & $25-30$ 年 & 3 & $2.9 \%$ \\
\hline & 30 年- & 10 & $9.6 \%$ \\
\hline \multirow[t]{4}{*}{ 勤務年数 } & 0-1 年 & 13 & $12.5 \%$ \\
\hline & 1-5 年 & 38 & $36.5 \%$ \\
\hline & 5-10 年 & 44 & $42.3 \%$ \\
\hline & 10-15 年 & 9 & $8.7 \%$ \\
\hline 合 計 & & 104 & $100.0 \%$ \\
\hline
\end{tabular}

践」の相関係数と「薬歴の実践」から「学ぶ姿勢」 へのパス係数は $1 \%$ 水準で有意であった.

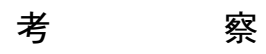

共分散構造分析の結果，「患者アセスメント」と 「薬歴の実践」の因子間に 0.73 と高い相関が得られ た。このことにより，薬歴の実践ができる薬剤師は 患者アセスメントができている薬歴となっていると 考えられる．また，患者アセスメントができている 薬歴を実践するためには薬歴の実践を行うことが基 盤になっているとも考えられる。また，「SOAP 記 録」が「学ぶ姿勢」と「薬歴の統一性」の 2 つの因 子から影響を受ける結果となった。これは，現在当 薬局の薬歴記載において「SOAP 記録」が主流と なっているためと考えられる. ${ }^{3)}$ そのため，学習に 関する「学ぶ姿勢」と薬歴統一に関する「薬歴の統 一性」の影響を受けていると考えられる。しかし， 記録のみでは薬歴の充実化は図れないためパス係数 が低いと考えられる。「薬歴向上意識」は「患者ア セスメント」と「学ぶ姿勢」の影響を受ける結果と なった，さらに，「薬歴向上意識」は「薬歴の統一 性」に影響を与える結果となった。これは，「患者 アセスメント」の薬歴への関心と個々の意識レベル の高まりが薬歴をよくしたいという意識を生むと考 えられる。そして薬歴をよくしたいという意識が, 
Table 4. Results of Factor Analysis

\begin{tabular}{|c|c|c|c|c|c|c|}
\hline \multirow{2}{*}{ 観測変数 } & \multicolumn{6}{|c|}{ 因 } \\
\hline & 1 & 2 & 3 & 4 & 5 & 6 \\
\hline 患者情報の確認・指導検討 & 0.766 & 0.177 & 0.022 & -0.101 & -0.018 & -0.116 \\
\hline 患者ケア評価 & 0.644 & 0.029 & 0.267 & -0.079 & -0.018 & -0.026 \\
\hline ケアプラン文書化 & 0.544 & -0.074 & -0.083 & -0.017 & 0.094 & 0.205 \\
\hline ケアプラン実施 & 0.493 & -0.021 & 0.153 & 0.164 & -0.001 & 0.131 \\
\hline 外部講師症例検討会 & 0.111 & 0.813 & -0.270 & 0.032 & 0.108 & 0.109 \\
\hline 自己変化意識 & -0.038 & 0.715 & 0.078 & 0.081 & -0.036 & 0.131 \\
\hline 薬歴管理の有効性 & 0.049 & 0.691 & 0.298 & -0.192 & -0.039 & 0.124 \\
\hline SOAP 記録 & -0.147 & 0.588 & -0.164 & -0.008 & 0.384 & -0.099 \\
\hline 薬歴評価希望 & 0.204 & 0.479 & 0.095 & 0.134 & -0.259 & -0.030 \\
\hline アウトカム思考 & 0.155 & -0.147 & 0.684 & 0.166 & -0.169 & -0.034 \\
\hline POS & 0.282 & -0.075 & 0.647 & -0.146 & 0.031 & 0.015 \\
\hline 患者個別状況把握 & 0.031 & 0.015 & 0.602 & -0.074 & 0.115 & 0.033 \\
\hline ケアプラン継続 & 0.046 & 0.201 & 0.522 & 0.061 & 0.031 & -0.068 \\
\hline ワークショップ開催 & 0.116 & -0.101 & -0.122 & 0.835 & -0.103 & 0.064 \\
\hline 薬局内統一意識 & -0.199 & -0.004 & 0.250 & 0.725 & -0.013 & 0.103 \\
\hline 薬局内検討会開催 & 0.052 & -0.180 & -0.050 & 0.701 & 0.098 & -0.017 \\
\hline 症例検討会開催 & 0.133 & 0.116 & -0.058 & 0.685 & -0.096 & -0.072 \\
\hline ケアの視点・プランニング & 0.067 & 0.331 & -0.042 & 0.597 & -0.137 & -0.049 \\
\hline 薬歴の一覧性 & 0.062 & 0.024 & -0.042 & -0.051 & 0.805 & 0.069 \\
\hline 薬局の薬歴統一性 & -0.030 & 0.084 & 0.082 & -0.086 & 0.609 & 0.056 \\
\hline 会社の薬歴統一性 & 0.277 & -0.092 & -0.014 & -0.038 & 0.481 & 0.141 \\
\hline ケアプラン立案難 & -0.001 & 0.056 & 0.144 & -0.143 & 0.207 & 0.701 \\
\hline プロブレムリスト抽出難 & -0.071 & -0.065 & -0.045 & 0.163 & 0.166 & 0.683 \\
\hline 評価の実行難 & -0.067 & 0.132 & -0.101 & 0.106 & 0.034 & 0.581 \\
\hline プロブレムの実行困難 & 0.194 & 0.086 & -0.236 & -0.031 & -0.179 & 0.489 \\
\hline
\end{tabular}

Table 5. Factor Names

\begin{tabular}{cc}
\hline \hline 因 子 & 因子名 \\
\hline 1 & 患者アセスメント \\
\hline 2 & 学ぶ姿勢 \\
\hline 3 & 薬歴の実践 \\
\hline 4 & 薬歴向上意識 \\
\hline 5 & 薬歴の統一性 \\
\hline 6 & 薬歴の問題点 \\
\hline
\end{tabular}

薬歴の統一性につながると考えられる.

6 因子モデルでは, 「薬歴の問題点」が他の因子 の影響を受けている結果となった。これは「薬歴の 問題点」というものが，いろいろなもので構成され るためと考えられる。このモデルにおいて，「薬歴 の問題点」は薬歴の実践を行うことで改善される結
果となった．また「学ぶ姿勢」は，「薬歴の実践」 の影響を受けている結果となった。このことから 「学ぶ姿勢」を中心に考えると，同程度の学ぶ姿勢 を持っている人では，「薬歴の実践」を行っている 人の方が, 「薬歴の問題点」についてはあまり意識 していない傾向にある。「薬歴の実践」は, 個々の 意識レベルを上げる。「学ぶ姿勢」が高まると，薬 歴の問題を考える傾向にあると考えられる。 しか し,「薬歴の問題点」への影響が低いため, このモ デルのみでは解決することは困難であると思われる.

そこで,「薬歴の問題点」を除外した 5 因子モデ ルを作成した.このモデルは, より薬歴を向上した いという意識を明確にする結果となった。「学ぶ姿 勢」は, 自分の薬歴管理の内容をよくしたい, 外部 講師から学びたい, 薬歴を誰かに評価してもらいた いというものに影響がある．このことより，個人の 学ぶ姿勢が高いことを意味していると考えられる. 


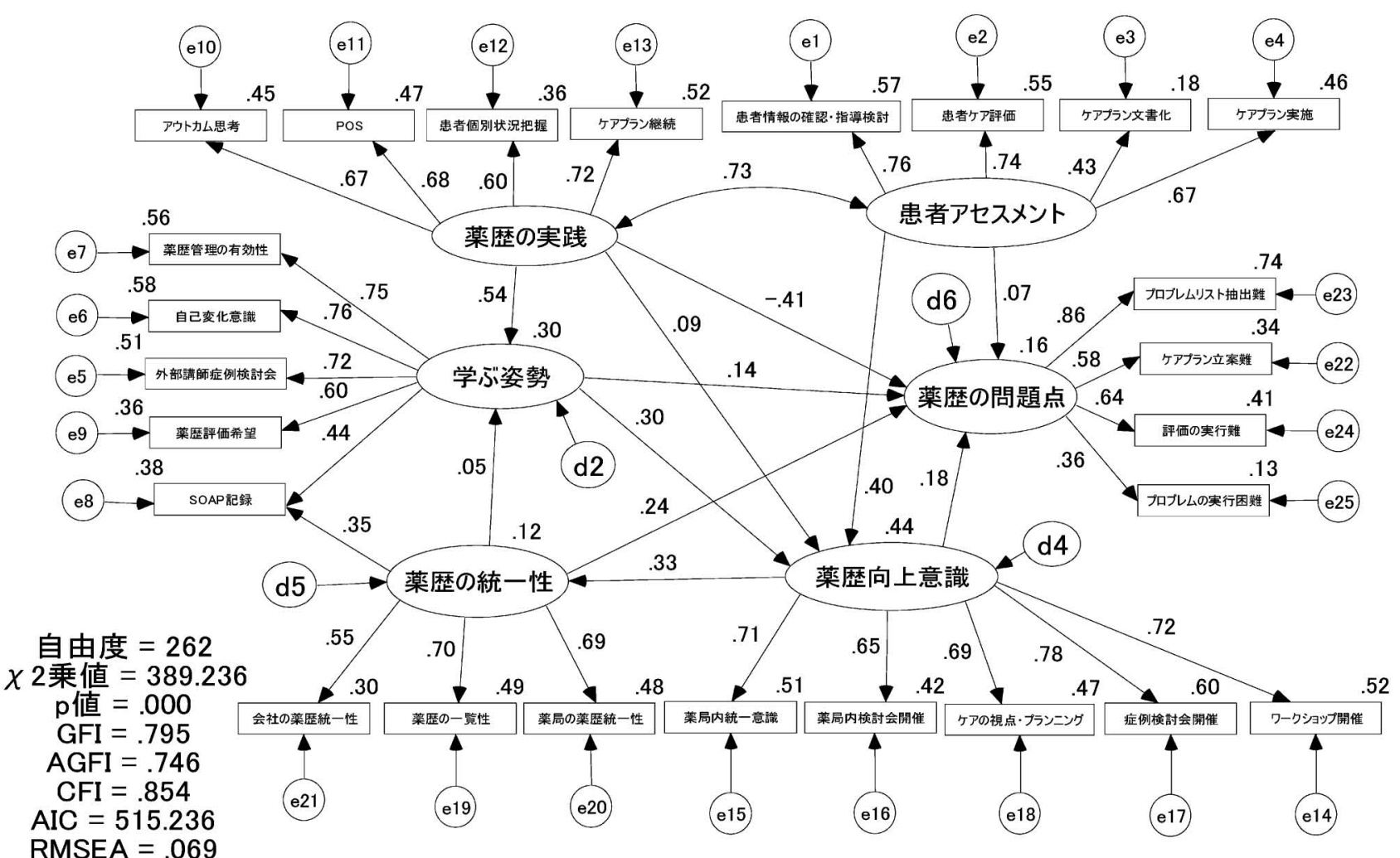

Fig. 2. Path Diagram (Six-factor Model)

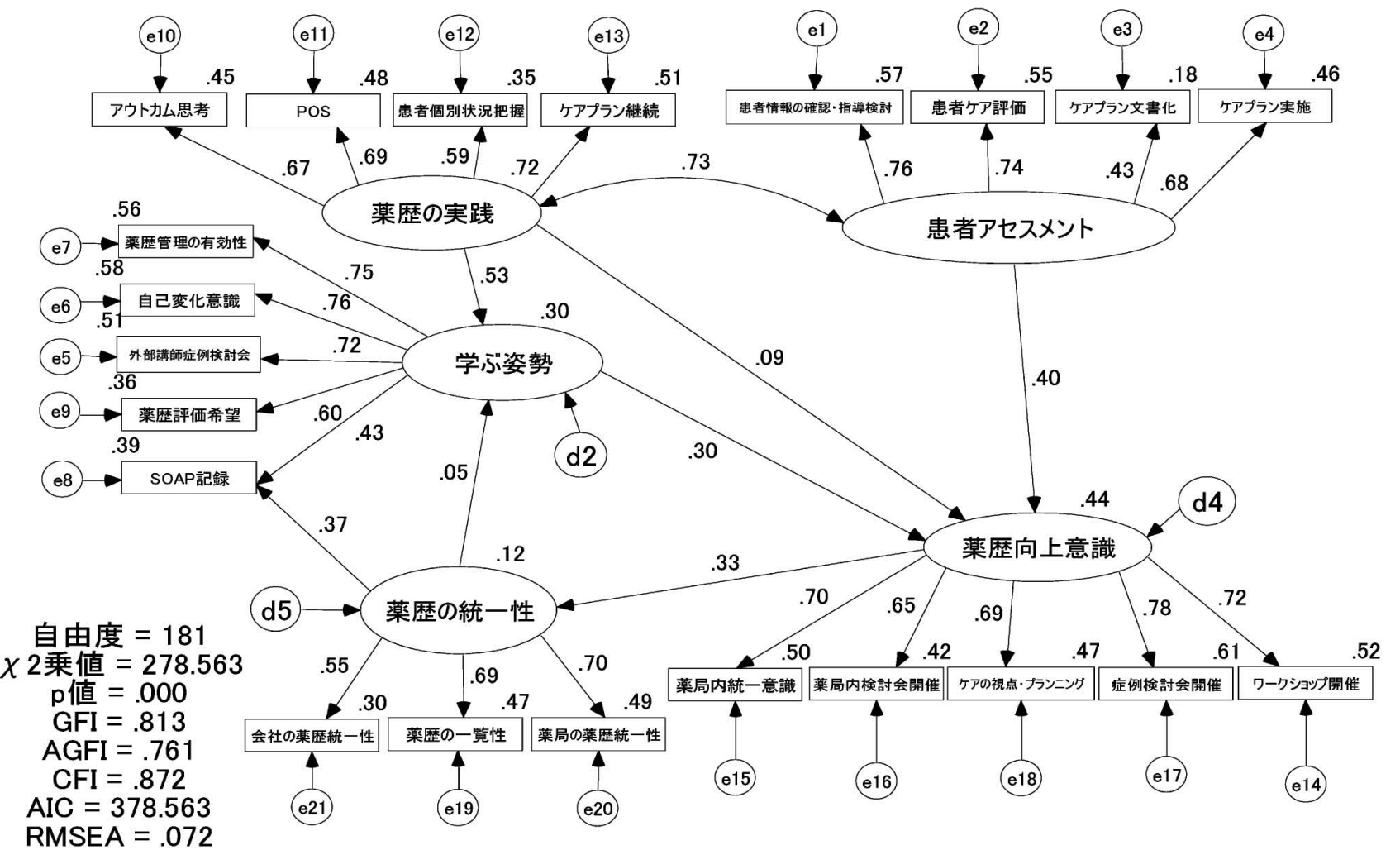

Fig. 3. Path Diagram (Five-factor Model) 
また，「薬歴向上意識」はワークショップや症例検 討会の開催に影響する。薬歴管理に必要とされるよ り具体的な内容を学ぶことが向上意識につながるこ とを意味していると考えられる.

6 因子モデルでは，薬歴の問題が中心となるモデ ルとなった。一方，5因子モデルでは向上意識が中 心となる。このことにより，現段階での薬歴への意 識は薬歴の問題点を修正・改善するという意識より もまずは個人の薬歴のレベルを上げる意識の方が重 要視されていると考えられる，さらには，薬歴の問 題点がどのようなものであるのかが把握できず，そ の結果薬歴の問題点を修正・改善するレベルまで達 していないと考える人が多いと考えられる。パス図 の結果では，当薬局に勤務する薬剂師が実際に困難 と考えているのは「プロブレムリストを立案する」 と「薬学的評価を行う」である。そして現段階での 改善方法としては，実践を通してのスキルアップが 重要と考えられる，その際，資料を活用することも 有効であると考えられる. ${ }^{1-3,5,6)}$ また，「患者アセス メント」が「薬歴の問題点」への影響が少ない結果 となった。これは，薬歴を参考にするのが薬剤師の みのためと考えられる。このことより当薬局に勤務 する薬剤師の薬歴は，薬を中心とした意識の内容で 行っていると考えられる。一方，病院に勤務する薬 剂師の薬歴は，医師や看護師に参考にされるため医 療を中心とした意識の内容で行われていると考えら

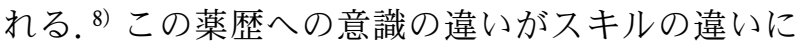
相当するものと考えられ，「患者アセスメント」を 意識した薬歴へ改善する必要性があると考える。パ ス図からは，患者ケアやケアプランについて影響度 が高いという結果となつた。このことは，ファーマ シューティカルケアの理解と実践が薬歴の改善につ ながることを示唆している.

今回の 6 因子モデル・5 因子モデルは, 仮説モデ ルとは若干異なるモデルとなったが，薬歴に関して より充実した内容にするための姿勢や意識が高いこ とが明らかとなった。しかし，内容を充実しただけ では薬歴の問題点の明確化や解決するには至らない ことも明らかとなった。患者アセスメントスキルと 実践は強く関連しており，この関連性が学習姿勢や 向上意識につながっていることが明らかとなった。 問題点の明確化や改善に関しては，「患者アセスメ ントスキルの向上」と「薬歴の実践力の向上」から
「向上意識」，「学習姿勢」，「統一化」につなげてい くことが必要であり，これらの実践を通して薬歴の 標準化が可能になると考える.

結論

本研究では，共分散構造分析を用いることによ り，当薬局に勤務する薬剤師における薬歴への意識 を解析することができた．本研究はあくまでライブ リーという一薬局に勤務する薬郕師の意識レベルで あるが，今後，薬歴の問題点の明確化・改善するた めの研修内容を作成・実施し，さらに実際の業務で の薬歴管理の調査を行い，その結果を精査すること で，多くの薬局で応用し得る薬歴管理の質的向上と 標準化へつながると考える.

\section{REFERENCES}

1) Hayakawa T., "Yakureki Skill Up Toranomaki Kihonshikkan-hen," Nikkei Business Publications, Inc., Tokyo, 2006.

2) Hayakawa T., "Yakureki Skill Up Toranomaki Manseishikkan-hen," Nikkei Business Publications, Inc., Tokyo, 2008.

3) Hayakawa T., "Yakureki Skill Up Toranomaki Senmonshikkan-hen," Nikkei Business Publications, Inc., Tokyo, 2009.

4) Hepler C. D., Strand L. M., Am. J. Hosp. Pharm., 47, 533-543 (1990).

5) Kimura T., Nagahashi K., Teraswa T., Hara T., "45 Shikkan no Yakugaku Kanri Check Note,"' Jiho, Inc., Tokyo, 2008.

6) Okamura M., "SOAP Perfect Training," Shindan-to-Chiryosha, Tokyo, 2010.

7) DiPiro J. T., Talbert R. L., Yee G. C., Matzke G. R., Wells B. G., Posey L. M., "Pharmacotherapy: A Pathophysiologic Approach," Brain Shuppan, Tokyo, 2007, pp. 51-66.

8) Kimura T., Yakugaku Zasshi, 127, 245-246 (2007).

9) Toyoda H., "Kyobunsan Kozo Bunseki Nyumon-hen," Asakura Publishing Co., Ltd., Tokyo, 1998.

10) Toyoda H., "Kyobunsan Kozo Bunseki Gimon-hen," Asakura Publishing Co., Ltd., Tokyo, 2003.

11) Toyoda H., "Kyobunsan Kozo Bunseki Jireihen," Kitaohji Shobo, Kyoto, 1998. 
12) Toyoda H., “Kyobunsan Kozo Bunseki Amos-hen,', Tokyo Tosho Co., Ltd., Tokyo, 2007.

13) Shimamori Y., Sato H., Hayase Y., Yakugaku Zasshi, 126, 273-282 (2006).

14) Sakurai H., Kawahara S., Tada Y., Nakajima F., Igari T., Momose H., Kondo H., Komori Y., Hayase Y., Yakugaku Zasshi, 127, 1115-
1123 (2007).

15) Sakurai H., Onda M., Konno H., Arakawa I., Hayase Y., Yakugaku Zasshi, 128, 625-633 (2008).

16) Sakurai H., Konno H., Shimori Y., Sugiyama H., Yoshimachi M., Kouno H., Gotou T., Hayase Y., Yakugaku Zasshi, 129, 557-568 (2009). 